
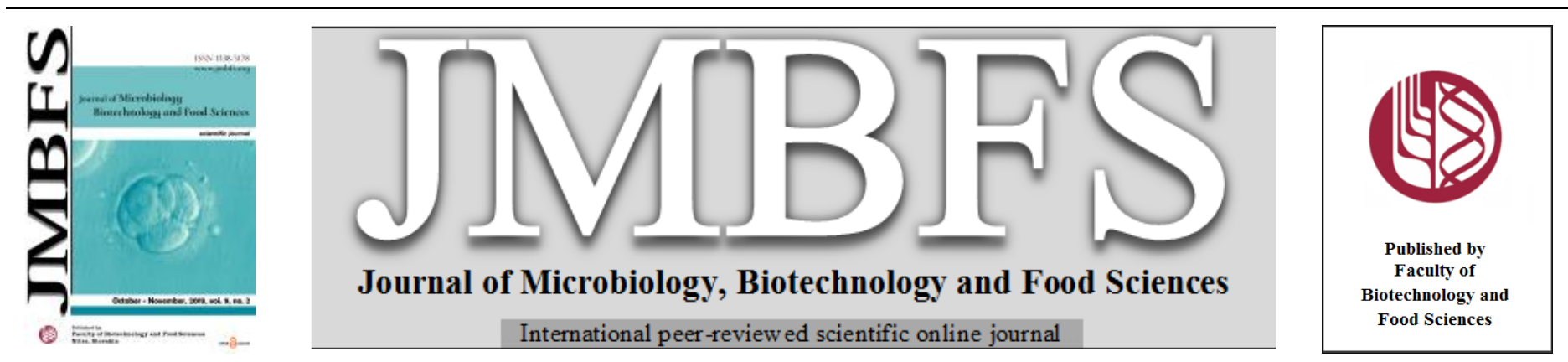

\title{
OAT: A NOVEL THERAPEUTIC INGREDIENT FOR FOOD APPLICATIONS
}

\section{Saniya Ramzan}

\author{
Address(es): \\ National Institute of Food Science and Technology, University of Agriculture, Faisalabad-38040, Pakistan.
}

*Corresponding author: saniyaramzan8@gmail.com

doi: $10.15414 / j m b f s .2020 .9 .4 .756-760$

\section{ARTICLE INFO}

Received 1.6. 2019

Revised 6. 9. 2019

Accepted 11.9. 2019

Published 3. 2. 2020

Review

open $\odot$ access

\begin{abstract}
Oat is a cereal grain that is known for its good nutritional composition with extra benefit of the $\beta$-glucan as dietary fiber. It is one of the major crop that is grown in different countries as by product or for non-food use. Now researchers and scientists have discovered its phenomenal properties that tends to help the human beings to combat with the ailments. Further, it also act as preventive measure to cure starting point of some chronic diseases such as heart diseases, gastrointestinal diseases, diabetes and cancer. Moreover it also acts as antimicrobial, antioxidant and reduces the blood cholesterol level. There is a tremendous increase in the number of oat products in the market that can soon take over the traditional products. These products include whole products, breakfast meals, flakes, porridge, bread, bars, drink like oat milk and yogurt like fermented commodities. Based on these beneficial effects and increasing demand, oat is of major interest for commercial production of novel food products.
\end{abstract}

Keywords: $\beta$-glucan, antioxidant, LDL cholesterol, body mass index, probiotic

\section{INTRODUCTION}

Avena sativa: common name oat, groats, haber, hafer, avena, straw, oatmeal, family poaceae, genus Avena was originated from European countries. Afterwards, it is now cultivated throughout the world. Avena is derivative of the Sanskrit word "avi," means "avasa" or "sheep" is the denotation of "foodstuff." The wild species of A. sativa is A. sterilis which is naturally present in the Crescent of the Near East. Oat is generally considered derived from a weed of wheat and barley as secondary crop leading to its ultimate domestication. Oat has been cultivated for 2000 years in different areas worldwide. According to the UN Food and Agriculture organization (FAO STAT, 2014) the overall world production of oat was around 25.8 million metric tons (mmt); Russia was the top producer $(5.8 \mathrm{mmt})$ with following countries contribution by production of oat Canada $(4.2 \mathrm{mmt})$, United States $(1.3 \mathrm{mmt})$, Poland $(1.2 \mathrm{mmt})$, Finland $(1.2$ $\mathrm{mmt})$, Australia (1.2 mmt), Ukraine (0.9 mmt), Germany, Belarus, and China, $(0.8,0.6$, and $0.4 \mathrm{mmt}$, respectively). Avena sativa (white oats) and Avena byzantine (red oats) are the two cultivars that are commonly cultivated throughout the world but Russia, the European Union including Finland and Poland, Canada, USA and Australia are the major producers (Daou \& Zhang, 2012).

Normally in countries like Pakistan, it has mostly non-food use such as animal fodder. Furthermore, its straw has also a wide range of uses such as for bio-mass, fiber, building board, mulch, thatching, paper-making and also as a stuffing material for mattresses. Extract of oat straw prevents the striped cucumber beetle feeding. While oat hulls are used for the manufacture of furfural, a chemical intermediate used for the preparation of nylon, butadiene, phenolic resin glues, lubricating oils and rubber tread constitutions. It is also important in the manufacture of construction boards, cellulose pulp and filter in breweries. Now there is increased trend oat usage for medicinal purposes as well as a food (Singh et al., 2013).

It has a number of unique properties that makes them different from other cereal grains. As for instance, their hull is separate from endosperm that contains higher fat content among cereal grains. It is also known for its high percentage of soluble dietary fibers. The outer layer is a good source of neutral lipids, protein, phenolics, $\beta$-glucan and niacin. The groat is a complex structure having three distinctive regions namely bran, endosperm and germ. These fractions are acquired during oat milling (Gates \& Dobraszczyk, 2004). The endosperm part of the grain is about 80 percent and out of that the inner endosperm part contains starch, proteins, lipids and $\beta$-glucan. The germ portion is about 3.7 percent of groat that consists of mainly proteins, hydrolytic enzymes and lipids. This portion is known for the better storage stability. The oat bran portion has high amount of $\beta$-glucan and now due to that fiber content it is becoming a commercial source of $\beta$-glucan that helps in reduction of blood cholesterol (Gangopadhyay et al. 2015). $\beta$-glucan is non-starch polysaccharide that consist of $D$-glucose monomer units connected by $\beta$-glycosidic bonds. $(1,3)(1,4)-\beta$-D-glucan (Fig 1 .) is present in endosperm and sub-aleurone part of oat seeds. $\beta$-glucan is soluble and fermentable fiber that is found to be $3-8 \mathrm{~g}$ in oat (Khoury et al., 2012). Oat is a uniquely nutritive food due to an excellent profile of lipid. The lipid exists as lipid bodies, similar to emulsion droplets, surrounded by proteins and phospholipids. These lipid bodies with proteins can be extracted from oats by addition of salt and water to obtain oat milk (Decker et al., 2014).

The health benefits of dietary fiber have led to in its use in all food product categories. That includes production of many by extruded product's processing where expansion provides textures to make the food crispy and appetizing (Moraru \& Kokini, 2003). Oat contains rich protein contents. It is the only cereal comprises avenalin $(80 \%)$, globulin or legume-like protein, as its main storage protein. Other type of cereal proteins present are gluten and zein. The minor contents of avenin are also present. Oat protein is nearly correspondent in quality to protein of soybean. That according to WHO is equivalent to that of meat, milk, and egg protein. Moreover tocols, avenanthramides, flavonoids, lipids, alkaloids, sterols and saponins are also present in it. Oat in early ages was used to treat nervous exhaustion, insomnia, and weakness of the nerves. They were reflected as antispasmodic, antitumor, diuretic, cyanogenetic, demulcent, stimulant, neurotonic, tonic, and vulnerary (Singh et al., 2013).

\section{THERAPEUTIC POTENTIAL}

\section{Hypocholesterolemic activity and cardiovascular ailments}

Oat products have an effect of lowering the cholesterol level in normal and hypercholesterolemic patient. It causes a significant reduction in Low Density Lipoprotein (LDL) (Truswell. 2002). LDL normally called as bad cholesterol due to its moveability in the blood vessels and it can stick to the walls of artries causing blockage for blood circulation. Oat soluble fiber with low saturated fat ans choleterol diet has proven to be effective for hypercholestremic and diabetic patients in lowering LDL concentration up to $5-10 \%$ (Khoury et al., 2012) According to a study by oat Anderson et al., $2009 \beta$-glucan helps to reduce up to 5.5 percent serum LDL cholesterol level that leads to the reduction of cardiovascular disease probability approximately 7 to 11 percent. While other studies like Martensson et al., 2005 and Kearney et al., 2011 have also supported the fact that oat based products e.g. oat based fermented product using Pediococcus parvulus helped in lowering the serum cholesterol. The mechanism behind bringing down the serum cholesterol by oat $\beta$-glucan is that it helps in the lowering of bile acid reabsorption that ultimately ends in the increament of Bile 
acid excretion in feces. That promotes more bile acid production by the liver utilizing cholesterol in the serum (Fig. 1) (Yao et al., 2006).

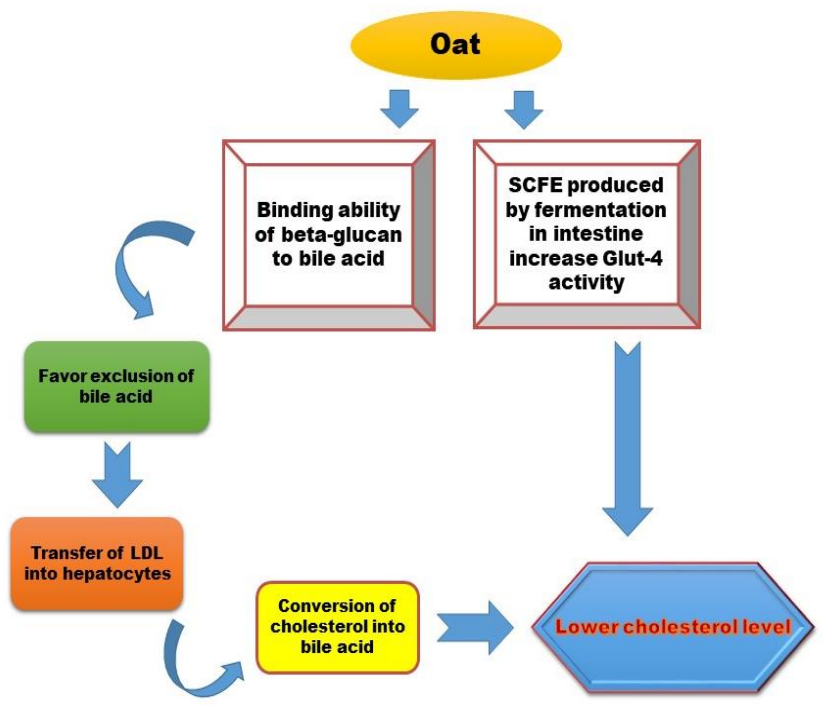

Figure 1 Oat beta-glucan binds with bile acid causes removal of bile acid from body leads to cholesterol conversion into bile acid. End result is lower cholesterol level in body. (mechanism of cholesterol lowering ability of oats)

Furthermore, eating of high fiber foods i.e., oat results in the prevention of heart disease (Djousse \& Gaziano, 2007). FDA have approved the beneficial health effects of oat bran fiber, soy protein and psyllium fiber that is associated with the prevention and cure of coronary heart disease (CHD) (FDA, 1997, 2008, 2017a,b). So, intake of dietary fiber is helpful in reduction of blood pressure. It is recommended for hypertensive persons to take up high amount of such fiber either from natural source or its supplements (Anderson et al., 2009)

\section{Antineoplastic behavior}

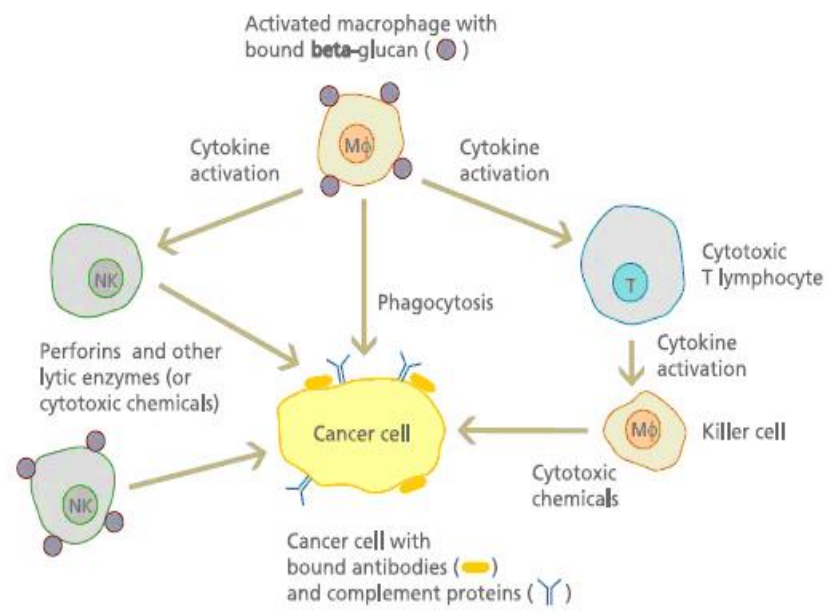

Figure $2 \beta$-glucan activate macrophages that helps in the cytotoxin chemical release either by $\mathrm{T}$ lyphocytes or lytic enzymes. These chemiclas destroy tumor. (anticancer mechanism)

Whole-grain food consumption results in lowering the risk of cancer. Selenium is used in DNA repair which is associated with less threat of cancer i.e., colon cancer. In the large bowel, soluble dietary fiber increases the fermentation activity, boosts growth and colonization of probiotic strains and thus helps in the removal of nitrogen by feces (Anderson et al., 2009). Moreover, $\beta$-glucan acts as antitumor and anticancer by just not only destroy tumor cells but also modulate the lymphocytes, natural killer cells, neutrophils and further components of immune system (Fig. 2) (Hong et al., 2004). The neutrophils (white blood cells) are the first line of defense of the body is involved in this antitumor activity. The combination of $\beta$-glucan with other antibodies activate the neutrophils to search and bind with the tumor that starts destroying the tumor. But normally these neutrophils cannot recognize the cancerous cells (Daou \& Zhang, 2012) Furthermore, $\beta$-glucan was also helpful in significantly increasing proliferation and activation of monocytes in peripheral blood of persons suffering from breast cancer (Demir et al., 2007).

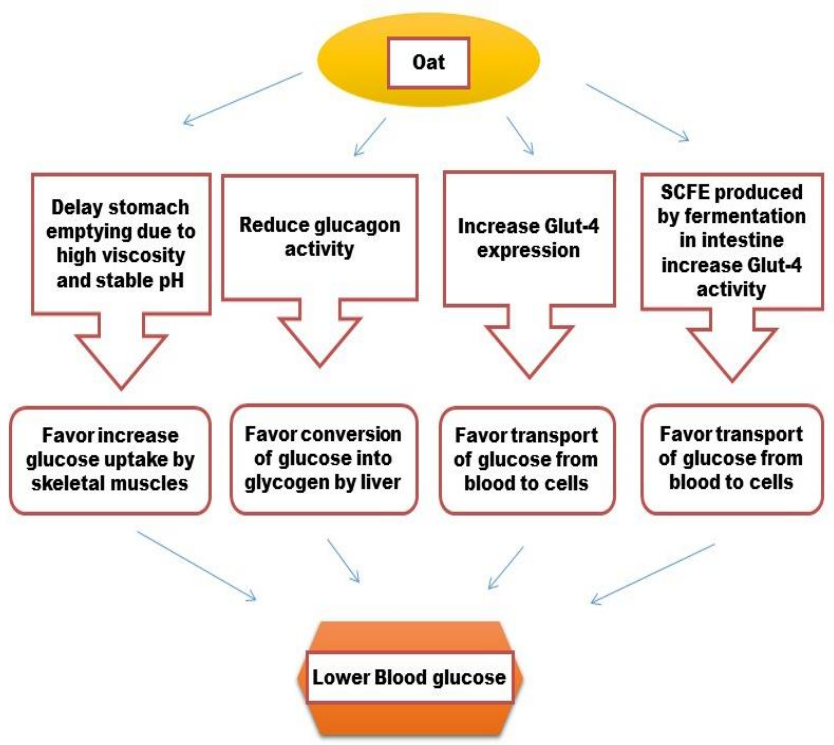

Figure 3 Oat working as antidiabetic: mechanism

\section{Antidiabetic activity}

Oat $\beta$-glucan has the power to lower the glycemic response. The Glycemic index (GI) is an indicator that shows the consumption of carbohydrate can increase the blood glucose level that ultimately is the cause of development of type 2 diabetes and coronary heart disorder. A class of food that is referred as functional food with low GI helps to protect the persons from the danger of such diseases. That includes oat because its bran is known for lower in cholesterol and high in $\beta$ glucan (Jenkins et al., 2002). Another study by Wood, 2007 had revealed the relation between the oat $\beta$-glucan with glucose and insulin in human body. As the $\beta$-glucan create a viscosity that affects the glucose and insulin linearly in a highly significant way. The way of oat lowering the blood glucose level is multiway mechanism by converting glucose into glycogen and increase the glucose uptake by body for its breakdown as energy source (Varma et al., 2016) (Fig. 3) Further, due to its linear and unbranched molecules chain it can make a highly viscous solution. That leads to the delayed gastric emptying and subsequently lower enzyme diffusion. Hence this will increase the muscular cells to uptake more glucose for utilization and lowering the blood glucose level. Another way to lowering the blood glucose in the body is resultant short chain fatty acids formed by the fermentation of beta-glucan. Insulin responsive glucose transporter type 4 (GLUT-4) is increased by these short chain fatty acids that affects the glucose-insulin homeostasis (Khoury et al., 2012).

\section{Antioxidant potential}

Oat exhibits a good antioxidant activity. Mostly, the antioxidant ability of oat is from polar phenolic compounds. Most of the antioxidants like tocols, sterols, phytic acid and phenolic compounds are present in the outer portion of the grain Their ability is to protect the food by preserving its color, taste and preventing the rancidity. Phenolic compounds are known for different biological effects including anti-oxidation, anti-inflammation, anti-allergic and anti-carcinogenic Oat contains avenanthramides, phenolic acids and flavonoids as phenolic compounds (Xu et al., 2009). Novel oat products are taking control over the market of functional foods for their ability of having bioactive compounds that exhibit antioxidant activity. Free radicals present in the body can act as damaging entity by starting chain reactions and affect the cellular components and DNA of the cell. Antioxidants act as hindrance for them by neutralizes them (Fig. 4) and prevent their activity (Tiwari \& Cummins, 2009).

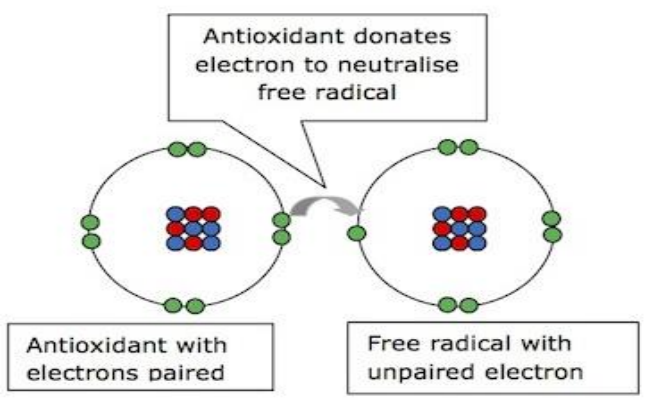

Figure 4 Antioxidant neutralizes free radical preventing chain reactions: mechanism 


\section{Weight managemen}

Oat contains $\beta$-glucan which is reported to reduce the body weight and Body mass index (BMI) considerably. A constant intake of oatmeal reduces the risk of obesity (Artiss et al., 2006). Anderson $\boldsymbol{e t}$ al., 2009 have reported during his studies that there was a significant impact of oat consumption on Chinese residents to lower their BMI, blood pressure and Serum HDL and LDL cholesterol values. The mechanism behind this phenomenon is that dietary fiber present in oat absorbs water, swell and increase its volume. That increased volume affects the satiety of the individual by distension of stomach (Daou $\boldsymbol{\&}$ Zhang, 2012) (Fig. 5). This increased viscosity also results in the slow digestion, delay of gastric emptying and lower nutrient absorption such as glucose. This makes the low enzymatic activity leads to the satietal sensations. Moreover, there is an inverse relationship found between the satiety and palatbility. Fiber-rich meals have lower palatability that will leads to early satisfication of consumer and ultimately lower body weight (Khoury et al., 2012).

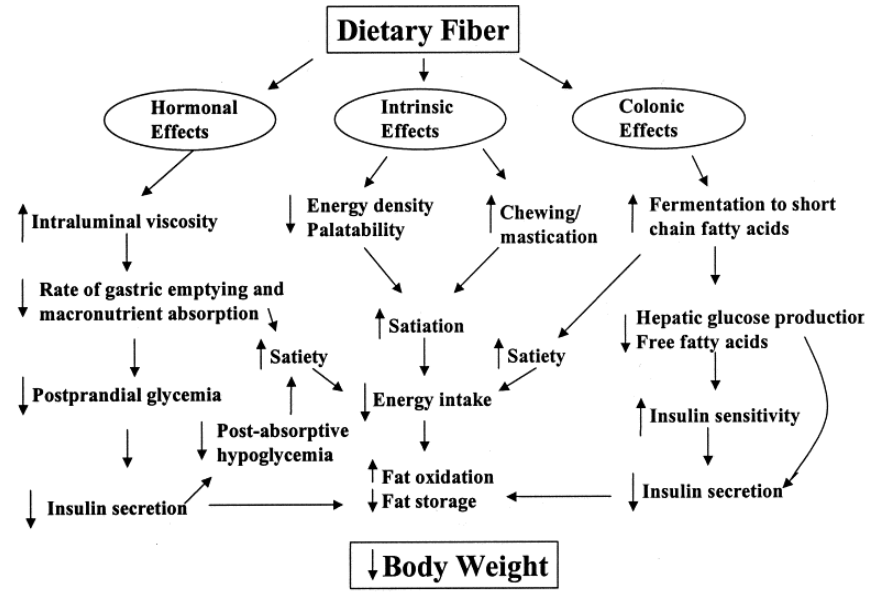

Figure 5 Mechanism of weight management by dietary fiber present in oat

\section{Celiac and Gastrointestinal disease}

Celiac disease is a disorder of the small bowel that is activated by exposure to gluten. Its symptoms are weight loss, chronic diarrhea and abdominal distention. Its treatment is life-long gluten free food. Oat is a gluten-free food component. The celiac disease patients can tolerate oat meals which is also high in fiber contents (Holm et al., 2006). Moreover its dietary fiber helps to improve bow movement and further beneficial bacterial proliferation in the gut. That helps to improve the celiac health of an individual. Ulmius et al., 2011 supported the fact by outcome of his study that $\beta$-glucan cannot be hydrolyzed by any enzyme in human beings so this remain intact in small intestine that ultimately results in increasing the viscosity of the area. The soluble and non-soluble fiber contents make oat a useful product for the prevention of many diseases, such as colon diseases. Moreover, these fiber acts as prebiotic that can help in the growth of beneficial microbes in the intestine. Those bacterias are also heplful in further prevention of diseases (Butt et al., 2008).

\section{Mental performance}

The wild green oat extract helps to improve the concentration, learning, and alertness during stressful conditions (Singh et al., 2013). Advanced studies on oats have shown that extract of green oats are helpful in improvement of human mental health. During an experiment a single oral dose that extract increase the theta electric brain activity in human that shows the indication of cognitive alertness. Such potential cognitive betterment shows the improved attentive behavior of a person and avoidance of distraction in attention and the ability to ignore distraction. Normally, the chronic effect of oat extract is more effective on persons with or at risk of mild cognitive disorder (Wong et al., 2012) Furthermore, the bioactive component of oat includes avenanthramides (bioactive compounds unique in oats) results in alleviate nitric oxide (NO) production in smooth muscles of human aorta. It inhibits nuclear factor $\kappa \mathrm{B}(\mathrm{NF}-\kappa \mathrm{B})$ activation that suppresses inflammatory cytokines. These mechanisms ultimately cause vasodilation in arteries of cerebral area (Mozolic et al., 2010). Brain activity is associated with oxidative cell stress. This can be implicated as stress and anxiety including neuropsychiatric disease (Bouayed et al., 2009). Immature oat seed can help for the cure of tension and anxiety: acute or chronic (Abascal and Yarnell, 2004). Studies done by Berry et al. 2011 showed beneficial effects of oat extracts on the elderly people of Australia with mild cognitive disorder during clinical trial conducted. The results showed better ability of people to focus and concentrate on task. Similar findings were also reported for the clinical trial of UK people by Kennedy et al. 2017.

\section{Bactericidal activity}

Avenacin, isolated from the oat root is a potential inhibitor for the growth of many of microorganisms (Singh et al., 2013). $\beta$-glucan present in oat is also reported to act as antibacterial by taking it intramuscularly/ intravenously/ orally it work on bacterial clearance by eliminating them. This antibiotic potential is influenced by increased cytokine production hence increasing the monocytes and neutrophils. The results of some studies made it evident that oat $\beta$-glucan taken orally imparted potential effects on HSV-1 respiratory infectious patients and also effective against macrophage antivirus. The mode of action of oat $\beta$-glucan as anti-microbe is by humoral immunity that is cellular and antigen specific Hence oat provides resistance against many bacterial and other parasitic infections (Daou \& Zhang, 2012). The beta-glucan present in oat can stimulate cellular immune system and increases humoral immunity. This results in the betterment of immune cells function and response to the bacterial attack (Vetvicka et al., 2007). Moreover, it also boosts the macrophages activity and helps in activation of neutrophils to act as antimicrobial cells (Zekovic et al. 2005). During a study on mice, Cheol-Heui et al., 2003 showed that $\beta$-glucans extracted from oats increased phagocytes activity and proved to be protective against Staphylococcus aureus and Eimeria vermiformis.

\section{Wound healing}

The activity of oat flour preparations was assessed on experimental wound healing models. The results of the study recommended the ability of oat to induce the cellular responses involved in wound healing (Singh et al., 2013). Moreover, other studies have also shown that oat has antitumor, antibacterial and wound healing functional bioactive compounds (Ohno et al., 2001).

\section{Cure of other ailments}

An extract of the green tops of oats is used as a nerve stimulant. It also helps in pulling out from tobacco and opium obsession. Moreover, oats were often used in baths to cure insomnia and anxiety. It is used to treat a number of skin conditions like burns and eczema. Patients suffering from cutaneous xerosis can be cured by lotion containing colloidal oat meal. During clinical trials, this lotion helped in the improvement of the problems including scaling erythema, pruritus, scratching wounds and lichenification (Pacifico et al., 2005; Reynertson et al., 2015). Oat used in the bath water helps to keep the skin soft due to its soothing effect. The seeds of oat are traditionally used as medications for tumors. Furthermore, the oat straws are useful in rheumatism. A tea made from oat was usually useful in rheumatic conditions and to treat water retention (Singh et al., 2013).

\section{FOOD APPLICATIONS}

Oats are processed to obtain various types of products or parts depending on their need. Such as 'Whole oat' that has a hard outer hull which should be removed for human intake. While 'Groats' are hulled oats that has hard inedible outer hul removed from the oat grain but the outer bran layer of kernel remain intact Furthermore, 'Coarse/cut groats' are steel-cut oats, and also referred as pinhead oats, coarse/rough oatmeal, that can be obtained using steel cutters for groats which cut down into 3-4 pieces. 'Rolled oats' are prepared by steaming groats followed by flattening them using a roller. Moreover, 'Instant oats' are made similarly like rolled quick-cooking oats but they are more thinly rolled and steamed for more time. Oat flour is ultimate product of oats that is obtained by grinding the oats. They are available in three grades: coarse, medium and fine oat flour (Winfield et al., 2007).

Oat is now more famous for its beneficial effects among the people and they want it in their products. Hence the industrial and commercial products containing oat are now present in the market vastly. It is commonly used in porridge. A deviation in porridge is due to fermentation with lactic acid bacteria. Oat flakes as breakfast meal are also popular that are present alone or in mixture with other cereals. Oat meal is the form of oat cereal product which is usually used as breakfast product. Furthermore, the popularity of oat consumption necessitates its incorporation into mainstream food products such as bread. The oat bread is currently wheat bread with up to $30 \%$ oats added in it (Gates \& Dobraszczyk, 2004). Moreover, energy booster bars in corporation of oat with other cereals is also very common now a days. Oat cake is also a UK based product.

There is an increasing trend of not only eatable products that contain oat but also drinkable products containing oat are making their way to the market and consumer need. As oat milk is a milk substitute used widely now-a-days due to increasing consumer demand. People are more conscious about their diet (Deswal et al., 2013). Water soluble extracts obtained from legumes, cereals, oil seeds or pseudo-cereals that are similar to milk by appearance are plant-based milk substitutes. These replacements are usually prepared by the extraction of plant material in water followed by the removal of solids and product formulation, afterwards, homogenization and heat-treatment is applied. The end product is the suspension of extracted plant material $\&$ its ingredients such as 
hydrocolloids and oils. Now-a-days their trend is increasing due to people's awareness about their diets, as a lifestyle choice or for medical reasons such as cow's milk allergy, lactose intolerance etc. Over the last 2 decades the utilization of cereal milks in the Western world has increased due to the increased health awareness of consumers, reduction of growth inhibitors and the minimization of off-flavors (Mäkinen et al., 2016). Cereal milk obtained by enzymatic hydrolyzing is a potential source of fat, protein and antioxidants (Suphamityotin. 2011). The cereal and grain milks are cholesterol and lactose free in comparison to bovine milk. So, they are an attractive substitute of bovine milk. Moreover, non-dairy vegetarians do also emphasis on its use rather than dairy or cultured dairy products (Durand $\boldsymbol{e t}$ al., 2003). Oat milk bars are also produced from the oat milk. Another product that is under tremendous observation of scientists is oat based yogurt like fermented product is developed using lactic acid bacteria which has high beta-glucan contents (Martensson et al., 2001). Oat milk helps to extravagant probiotic products that add the nutritional and functiona characteristics to cereal (Butt et al., 2008). Another product yogurt containing oat as additives in it is also produced for the consumers with high fiber content. To substitute the fat in low-fat meat products, oat fiber is most effective to mimic fat character (Havrlentova et al., 2011). Today's society has more number of persons suffering from fatigue and burnout. So, finding solutions other than antidepressant that are from natural sources is more beneficial. In the Asian countries there are a number of products that are available in the markets containing oat targeting mental health and cognitive problems (Abascal and Yarnell, 2004)

\section{CONCLUSION}

Oat is one of the gifts from our God that has phenomenal constituents that can be helpful in different conditions. Not only in non-food use but it has also outcaste the other cereal grains by acting as functional food. The FDA approved its usage for the beneficial effects on the coronary heart disease patients. Furthermore, it is also helpful in the prevention of other diseases such as diabetes, skin problems, obesity, cancer, gastrointestinal diseases etc. Now people are more aware abou their health and are conscious in their life style hence there is an increased demand of oat products and is increasing day by day. Most of the products are available in market and more are to come in near future due to keen interest of scientists in oat and its properties. Due to the the tremendous beneficial chracteristics, oat and its products will be prefered by the consumers rather than the staple food products and can lower the burden of the main food commodities of the area.

\section{REFERENCES}

Abascal, K., Yarnell, E. (2004). Nervine herbs for treating anxiety. Alternative and Complementary Therapies. 10: 309-315. http://dx.doi.org/10.1089/act.2004.10.309

Anderson, J.W., Baird, P., Davis, R.H., Ferreri, Jr.S., Knudtson, M., Koraym, A., Waters, V., Williams, C.L. (2009). Health benefits of dietary fiber. Nutrition Reviews. 67: 188-205. http://dx.doi.org/10.1111/j.1753-4887.2009.00189.x

Artiss, J.D., Brogan, K., Brucal, M., Moghaddam, M., Jen, K.L. (2006). The effects of a new soluble dietary fiber on weight gain and selected blood parameters in rats. Metabolism. 55: 195-202. http://dx.doi.org/10.1016/j.metabol.2005.08.012

Berry, N.M., Robinson, M.J., Bryan, J., Buckley, J.D., Murphy, K.J., Howe, P.R. (2011). Acute effects of an avena sativa herb extract on responses to the stroop color-word test. Journal of Alternative and Complementary Medicine. 17: 635-7. https://doi.org/10.1089/acm.2010.0450

Bouayed, J., Rammal, H., Soulimani, R. (2009). Oxidative stress and anxiety: relationship and cellular pathways. Oxidative Medicine and Cellullar Longevity. 2: 63-7. http://www.landesbioscience.com/journals/oximed/article/7944

Butt, M.S., Nadeem, M.T., Khan, M.K.I., Shabir, R., Butt, M.S. (2008). Oat: Unique among the cereals. European Journal of Nutrition. 47:68-79. http://dx.doi.org/10.1007/s00394-008-0698-7

Cheol-Heui, Y., Estrada, A., Kessel, A.V., Chul, P.I.B., Laarveld, B. (2003) Beta-glucan, extracted from oat, enhances disease resistance against bacterial and parasitic infection. FEMS Immunology and Medical Microbiology. 35: 67-75. https://doi.org/10.1016/S0928-8244(02)00460-1

Daou, C., Zhang, H. (2012). Oat Beta-Glucan: Its Role in Health Promotion and Prevention of Diseases. Comprehensive Reviews in Food Science and Food Safety. 11: 355-365. https://doi.org/10.1111/j.1541-4337.2012.00189.x

Decker, E.A., Rose, D.J., Stewart, D. (2014). Processing of oats and the impact of processing operations on nutrition and health benefits. British Journal of Nutrition. 112: 58-64. http://dx.doi.org/10.1017/S000711451400227X

Demir, G., Klein, H.O., Mandel-Molinas, N., Tuzuner, N. (2007). Beta glucan induces proliferation and activation of monocytes in peripheral blood of patients with advanced breast cancer. International Immunopharmacology. 7: 113-6. http://dx.doi.org/10.1016/j.intimp.2006.08.011

Deswal, A., Deora, N.S., Mishra, H.N. (2013). Optimization of enzymatic production process of oat milk using response surface methodology. Food and Bioprocess Technology. 7:610-618. http://dx.doi.org/10.1007/s11947-013-1144-2
Djousse, L., Gaziano, J.M. (2007). Breakfast cereals and risk of heart failure in the physicians' health study I. Archives of Internal Medicine. 167: 2080-2085 http://dx.doi.org/10.1001/archinte.167.19.2080

Durand, A., Franks, G.V., Hosken, R.W. (2003). Particle sizes and stability of UHT bovine, cereal and grain milks. Food Hydrocolloids. 17:671-678 http://dx.doi.org/10.1016/S0268-005X(03)00012-2

FAO Stat. (2014). Food and Agriculture Organization of United Nations. http://faostat.fao.org or $\quad$ http://www.fao.org/economic/the-statisticsdivisioness/publication-studies/statistical-yearbook/fao-statistical-yearbook2009/en/.

FDA (1997): Final rule for 'Food Labeling: Health Claims; Oats and Coronary Heart Disease'. Fed. Reg. 62, 3584-3681.

FDA (2008): Food Labeling: Health Claims; Soluble fiber from certain foods and risk of Coronary Heart Disease Interim final rule'. Fed. Reg. 73, 9938-47.

FDA (2017a): Final Rule for 'Food labeling: health claims: soy protein and coronary heart disease'. Fed. Reg. 64, 57699-57733.

FDA (2017b): FDA Consumer: Staking a Claim to Good Health. www.vm.cfsan.fda.gov/dma/fdhclm.html (accessed October 31, 2017).

Gangopadhyay, N., Hossain, M.B., Rai, D.K., Brunton, N.P. (2015). A review of extraction of bioactives in oat and barley and scope for the use of novel food $\begin{array}{llll}\text { processing technologies. } & \text { Molecules. } & \text { 20: } & 10884-10909\end{array}$ http://dx.doi.org/10.3390/molecules200610884

Gates, F.K., Dobraszczyk, B.J. (2004). Mechanical properties of oats and oat products. Agricultural and Food Science. 13:113-123. https://doi.org/10.2137/1239099041837978

Havrlentova, M., Petrulakova, Z., Burgarova, A., Gago, F., Hlinkova, A., Sturdík, E. (2011). Cereal $\beta$-glucans and their significance for the preparation of functional foods - a review. Czech Journal of Food Sciences. 29: 1-14.

Holm, K., Maki, M., Vuolteenaho, N., Mustalahti, K., Ashorn, M., Ruuska, T. (2006). Oats in the treatment of childhood coeliac disease: A 2-year controlled trial and a long-term clinical follow-up study. Alimentary Pharmacology and Therapeutics. 23: 1463-1472. https://doi.org/10.1111/j.1365-2036.2006.02908.x

Hong, F., Yan, J., Baran, J.T., Allendorf, D.J., Hansen, R.D., Ostroff, G.R., Xing, P.X., Cheung, N.K., Ross, G.D. (2004). Mechanism by which orally administered $\beta$ - $(1,3)$-glucans enhance the tumoricidal activity of antitumor monoclonal antibodies in murine tumor models. Journal of Immunology. 173: 797-806. https://doi.org/10.4049/jimmunol.173.2.797

Jenkins, A. L., Jenkins, D.J.A., Zdravkovic, U., Wursch, P., Vuksan, V. (2002) Depression of the glycemic index by high levels of $\beta$-glucan fiber in two functional foods tested in type 2 diabetes. European Journal of Clinical Nutrition. 56: 622-628. https://doi.org/10.1038/sj.ejcn.1601367

Kearney, N., Stack, H.M., Tobin, J.T., Chaurin, V., Fenelon, M.A., Fitzgerald G.F., Ross, R.P., Stanton, C. (2011). Lactobacillus paracasei NFBC 338 producing recombinant beta-glucan positively influences the functional properties of yoghurt. International Dairy Journal. 21: 561-567. https://doi.org/10.1016/j.idairyj.2011.03.002

Kennedy, D.O., Jackson, P.A., Forster, J., Khan, J., Grothe, T., PerrinjaquetMoccetti, T., Haskell-Ramsay, C.F. (2017). Acute effects of a wild green-oat (Avena sativa) extract on cognitive function in middle-aged adults: A doubleblind, placebo-controlled, within subjects trial. Nutritional Neuroscience. 20: 135-151. https://doi.org/10.1080/1028415X.2015.1101304

Khoury, D.E., Cuda, C., Luhovyy, B.L., Anderson, G.H. (2012). Beta glucan: health benefits in obesity and metabolic syndrome. Journal of Nutrition and Metabolism. 2012: 1-28. http://dx.doi.org/10.1155/2012/851362

Mäkinen, O.E., Wanhalinna, V., Zannini, E., Arendt, E.K. (2016). Foods for special dietary needs: Non-dairy plant based milk substitutes and fermented dairy type products. Critical Reviews in Food Science and Nutrition. 56: 339-349. http://dx.doi.org/10.1080/10408398.2012.761950

Moraru, C.I., Kokini, J.L. (2003). Nucleation and expansion during extrusion and microwave heating of cereal foods. Comprehensive Reviews in Food Science and Food Safety. 2: 120-138. https://doi.org/10.1111/j.1541-4337.2003.tb00020.x

Martensson, O., Biörklund, M., Lambo, A.M., Chasco, M.D., Irastorza, A., Holst, O. (2005). Fermented, ropy, oat-based products reduce cholesterol levels and stimulate the bifidobacteria flora in humans. Nutrition Research. 25: 429-442. https://doi.org/10.1016/j.nutres.2005.03.004

Martensson, O., Andersson, C., Andersson, K., Oste, R., Holst, O. (2001) Formulation of an oat-based fermented product and its comparison with yoghurt Journal of the Science of Food and Agriculture. 81: 1314-1321. https://doi.org/10.1002/jsfa.947

Mozolic, J.L., Hayasaka, S., Laurienti, P.J. (2010). A cognitive training intervention increases resting cerebral blood flow in healthy older adults. Frontiers in Human Neuroscience. 4: 1-16. https://doi.org/10.3389/neuro.09.016.2010

Ohno, N., Miura, T., Miura, N.N., Adachi, Y., Yadomae, T. (2001). Structure and biological activities of hypochlorite oxidized zymosan. Carbohydrate Polymers. 44: 339-349. https://doi.org/10.1016/s0144-8617(00)00250-2

Pacifico, A., Angelis, L.D., Fargnoli, M.C., Felice, C.D., Chimenti, S., Peris, K (2005). Clinical trial on aveeno skin relief moisturizing lotion in patients with itching accompanied by skin lesions and xerosis. Journal of Applied Research. 5: 325-330. 
Reynertson, K.A., Garay, M., Nebus, J., Chon, S., Kaur, S., Mahmood, K., Kizoulis, M., Southall, M.D. (2015). Anti-inflammatory activities of colloidal oatmeal (Avena sativa) contribute to the effectiveness of oats in treatment of itch associated with dry, irritated skin. Journal of Drugs in Dermatology. 14: 43-48.

Singh, R., DE, S., Belkheir, A. (2013). Avena sativa (Oat), a potential neutraceutical and therapeutic agent: an overview. Critical Reviews in Food Science and Nutrition. 53: 126-144. https://doi.org/10.1080/10408398.2010.526725

Suphamityotin, P. (2011). Optimizing enzymatic extraction of cereal milk using response surface methodology. Songklanakarin Journal of Science and Technology. 33: 389-395.

Tiwari, U., Cummins, E. (2009). Factors influencing $\beta$-glucan level and molecular weight in cereal based products. Cereal Chemistry. 86: 290-301. https://doi.org/10.1094/CCHEM-86-3-0290

Truswell, A.S. (2002). Cereal grains and coronary heart disease. European Journal of Clinical Nutrition. 56: 1-14. https://doi.org/10.1038/sj.ejcn.1601283 Ulmius, M., Adapa, S., Onning, G., Nilsson, L. (2012). Gastrointestinal conditions influence the solution behaviour of cereal $\beta$-glucans in vitro. Food Chemistry. 130: 536-40. https://doi.org/10.1016/j.foodchem.2011.07.066

Varma, P., Bhankharia H., Bhatia, S. (2016). Oats: A multi-functional grain Journal of Clinical and Preventive Cardiology. 5: 9-17. https://doi.org/10.4103/2250-3528.183984

Vetvicka, V., Dvorak, B., Vetvickova, J., Richter, J., Krizan, J., Sima, P., Yvin, J.C. (2007). Orally administered marine $(1 \rightarrow 3)$ - $\beta$-d-glucan phycarine stimulates both humoral and cellular immunity. International Journal of Biological Macromolecules. 40: 291-298. https://doi.org/10.1016/j.ijbiomac.2006.08.009

Winfield K., Hall, M., Paynter, B. (2007). Milling oat and feed oat quality: What are the differences. Bulletin 4703. Department of Agriculture and Food, Government of Western Australia, pp. 10-12 http://researchlibrary.agric.wa.gov.au/bulletins

Wood, P.J. (2007). Cereal $\beta$-glucans in diet and health. Journal of Cereal Science. 46: 230-8. https://doi.org/10.1016/j.jcs.2007.06.012

Xu, J.G., Tian, C.R., Hu, Q.P., Luo, J.Y., Wang, X.D., Tian, X.D. (2009). Dynamic changes in phenolic compounds and antioxidant activity in oats (Avena nuda L.) during steeping and germination. Journal of Agricultural and Food Chemistry. 57: 10392-10398. https://doi.org/10.1021/jf902778j

Yao, N., Jannink, J.L., Alavi, S., White, P.J. (2006). Physical and sensory characteristics of extruded products made from two oat lines with different $\beta$ glucan concentrations. Cereal Chemistry. 83: 692-699. https://doi.org/10.1094/CC-83-069

Zekovic, D.B., Kwiatkowski, S., Vrvic, M.M., Jakovljevic, D., Moran, C.A (2005). Natural and modified ( $1 \rightarrow 3)-\beta$-D-glucans in health promotion and disease alleviation," Critical Reviews in Biotechnology. 25: 205-230. https://doi.org/10.1080/07388550500376166 